\title{
Numerical Modelling of Ballast Water Dispersion in Different Bioregions along the Coast of India
}

\author{
M.T. Babu' ${ }^{1}$, K. Sudheesh ${ }^{1}$, P.Vethamony ${ }^{1}$, and S. Anuvindha ${ }^{1}$ \\ ${ }^{1}$ CSIR-National Institute of Oceanography, Dona Paula 403004, Goa, India \\ *Corresponding author: mtbabu@nio.org
}

\author{
KEYWORDS \\ Ballast water \\ Bioregions \\ Dispersion \\ MIKE21 \\ Modelling
}

\begin{abstract}
Aquatic organisms and pathogens may become major threats to the coastal and marine environment when introduced into a region beyond their natural distributions through ballast water (BW). Coastal currents induced by tides and winds, especially flood currents, may facilitate the spread of these marine organisms along nearshore and inshore areas. Numerical modelling of hydrodynamics is an effective tool to track the dispersion of these organisms in the receiving water body through BW release. Particle transport models can be used to track the advection and dispersion of these organisms. Alternatively, the difference in salinity of the BW and coastal waters can be used as a tracer to estimate the dispersion pattern. Tides and winds present in the region at the time of BW release are responsible for the dispersal of the particles present in BW discharge. Based on advection and dispersion processes, the transport of the marine organisms present in the BW can be studied using numerical models. Numerical modelling studies were carried out using the 2-D hydrodynamic model MIKE21 HD, to understand the pattern of BW dispersion at select bioregions along the east and west coasts of India. Mangalore Port located along the west coast in Bioregion-I (CIO-I) and Chennai Port on the east coast in Bioregion-II (CIO-II) were selected for the modelling study. Results obtained from ballast water dispersion modelling studies will be useful for developing and assisting port-based ballast water management programmes for $\mathrm{ClO}-\mathrm{I}$ and $\mathrm{ClO}-$ II regions. The currents are predominantly tide driven near the ports situated along the west coast and the circulation exhibited reversals associated with the tidal currents. However, along the east coast of India, the particles largely followed coastal currents - advected either southward or northward under the influence of prevailing coastal currents in the offshore region and tidal reversals showed less impact. This information proved useful for determining suitable locations for BW discharge and monitoring points for field sampling in connection with BW release.
\end{abstract}

(c) The Author(s) 2018. This article is distributed under a Creative Commons Attribution-ShareAlike 4.0 International license.

\section{INTRODUCTION}

Ballast water (BW) carried by cargo ships has been identified as a major threat to coastal and marine environments as they unintentionally act as carriers of non-indigenous aquatic organisms and pathogens harmful to the marine environment (Medcof 1975; ; Endresen et al. 2004). These newly introduced species, also known as exotic species, when introduced into non-native regions, may grow and multiply very quickly in the absence of natural predators. These organisms can also spread in nearshore and inshore areas when carried by coastal currents or ebb/flood currents. Toxic algal species are expanding globally and BW could be the main carrier which helps in the spread of these species (Smayda 1990). The spread and uncontrolled growth of non-indigenous species, known as bio-invasion, will lead to environmental damage. In order to prevent bioinvasion, various ballast water management practices and discharge standards have been adopted by several countries. These methods are mainly intended to slow down or eliminate the introduction and dispersal of non-indigenous species and thereby effectively control bio-invasion. If any chemical treatment on BW is undertaken, the exposure towards chemicals can be estimated, based on laboratory testing of treatment systems, numerical models and expos- ure scenarios (Werschkun et al. 2014). Local currents driven by tides and winds are the main factors responsible for the advection and dispersion of the organisms discharged through BW. Thus, numerical modelling of hydrodynamics is an effective tool to track the probable dispersion pathways of these organisms when they reach the receiving water body through BW discharge. The particle tracking model can be applied to simulate the dispersion of marine organisms/larvae present in the BW. Alternatively, the difference in salinity of the BW and the coastal water can be used as a tracer to estimate the dispersion pattern, provided a significant salinity gradient exists between BW and the receiving water.

In the present work, MIKE21 numerical modelling software developed by the Danish Hydraulic Institute (DHI), Denmark was used to simulate the coastal hydrodynamics and physical transport of organisms, assuming salinity dispersion of BW. The purpose of this modelling is to determine the probable pathways of particles originating from a certain start position (BW discharge location). In the mod$\mathrm{el}$, the transport of particles is influenced by atmospheric forcing (consisting of wind, air pressure, temperature, precipitation and cloudiness), tides, residual currents, freshwater run-off, and temporal variation in salinity and temperature. Model studies have been carried out to sim- 


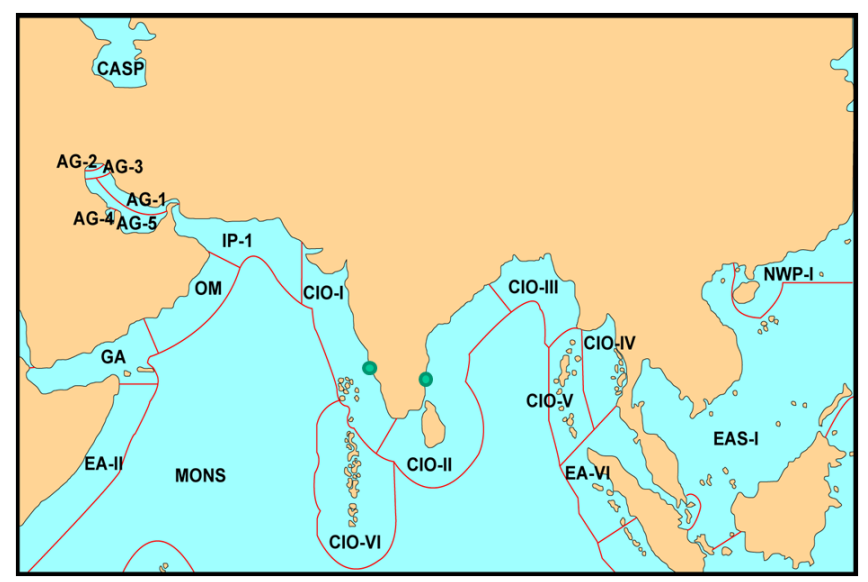

(A)

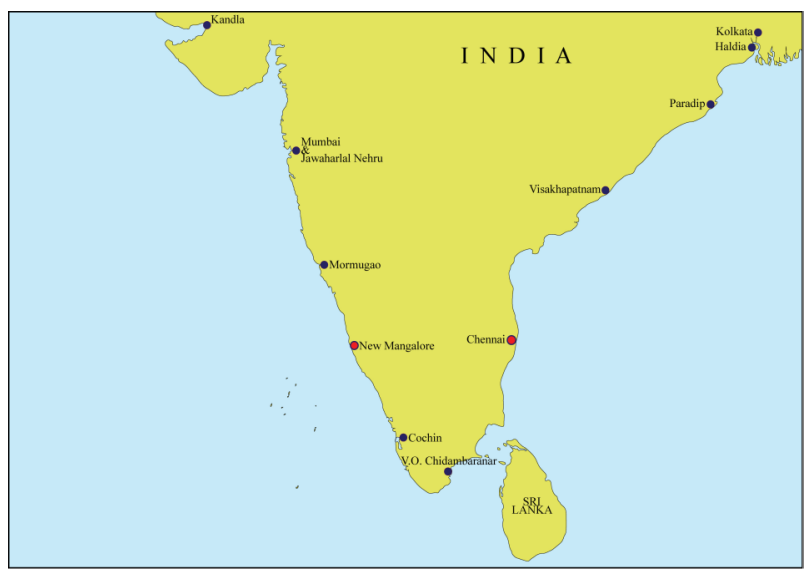

(B)

Figure 1. Marine bioregions in South and Southeast Asia, and major ports in India. (A) Marine bioregions, showing the code names of those in the South Asian region. (B) Locations of the ports selected for Phase I BWM study (shown in the highlighted box) The New Mangalore Port is in Bio region I, and Chennai Port in Bio region II.

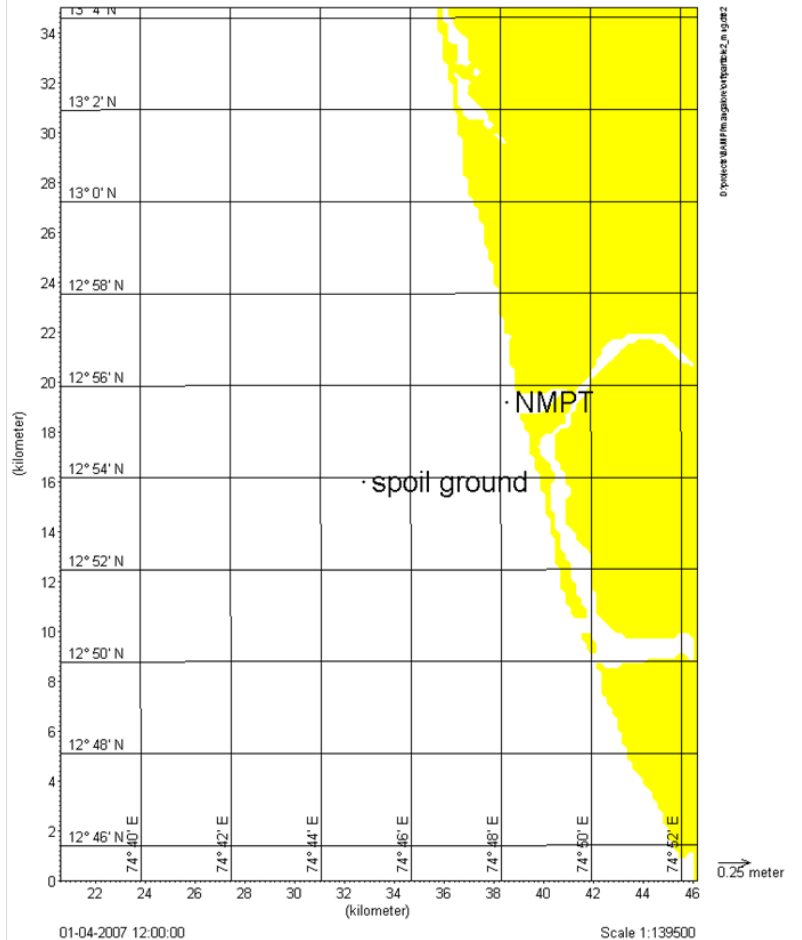

Figure 2. Ballast water discharge location $\left(12^{\circ} 54^{\prime} \mathrm{N}, 74^{\circ} 45^{\prime} \mathrm{E}\right.$, shown as red circle) off New Mangalore Port (NMPT), west coast of India.

ulate BW dispersion in North Sea and Baltic Sea (Gollasch et al. 2007; Stankiewicz et al. 2010, and Reise et al. 1999). Further, it is possible to connect the hydrodynamic model to an ecological or water quality model to study the spread of nutrients, planktonic and active moving species and settling benthic species.

Two ports located along the west and east coasts of India representing bio-regions I and II were selected to model BW dispersion.

\section{MATERIALS AND METHODS}

\subsection{Objectives and definition of bioregions}

Numerical modelling studies have been conducted to understand the pattern of BW dispersion at select bioregions along the coast of India. Two ports, namely, New Mangalore Port and Chennai Port (Figure 1A), were selected to study particle dispersion in CIO-I and CIO-II respectively.

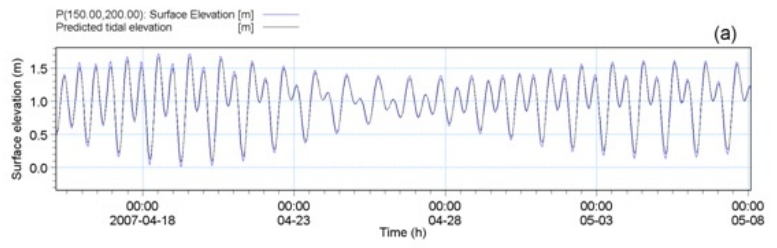

(A)

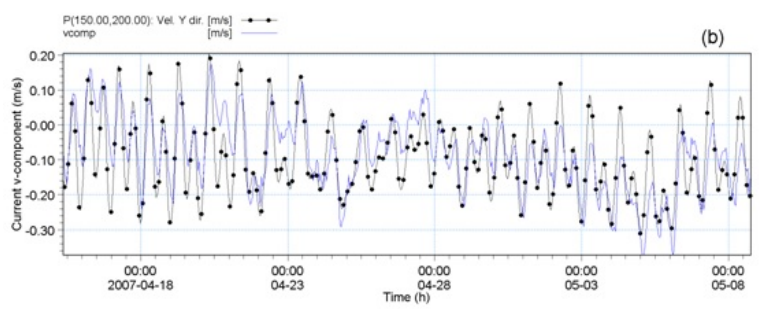

(B)

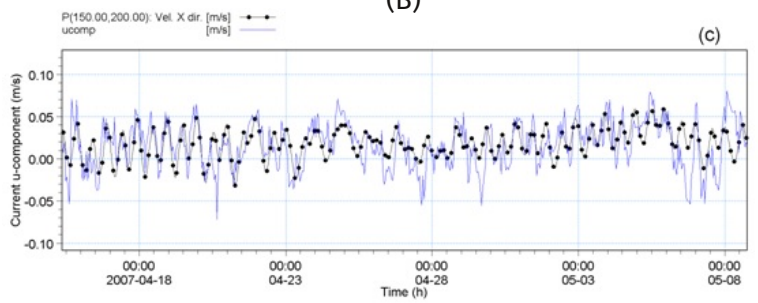

(C)

Figure 3. Modelled and predicted surface (tidal) elevations and currents at RCM1 location off Suratkal, west coast of India, between 12.04.2007 and 11.05.2007. (A) Model simulated and predicted surface tidal elevations; (B) v-component, and (C) u-component of currents. Blue lines indicate measured currents and black line with dots modelled currents in (B) and (C).

The New Mangalore Port is situated along the west coast of India in Bio region-I, and Chennai Port along the east coast of India in Bio-region-II (Figure 1B). These ports are major ports which receive bulk carriers and cargo ships from bioregions situated all over the world.

\subsection{Field data}

Detailed, site-specific information on the physical characteristics of the prevailing marine environment is a prerequisite to study the coastal hydrodynamics. Data on surface currents measured by Recording Current Meters (RCM) deployed in the vicinity of the spoil grounds of the two Ports were used to validate the model results. The locations of RCM deployment are given in Table 1. 
Table 1. RCM mooring locations

\begin{tabular}{lllr}
\hline & \multicolumn{2}{c}{ RCM Mooring Locations } & \\
\cline { 2 - 3 } Port & Latitude & Longitude & Depth $(\mathrm{m})$ \\
\hline New Mangalore & $12^{\circ} 54^{\prime} \mathrm{N}$ & $74^{\circ} 45^{\prime} \mathrm{E}$ & 15 \\
Chennai & $13^{\circ} 06.25^{\prime} \mathrm{N}$ & $80^{\circ} 19.48^{\prime} \mathrm{E}$ & 16 \\
\hline
\end{tabular}

\section{RESULTS AND DISCUSSION}

\subsection{Numerical modelling}

Numerical simulations of hydrodynamics were carried out for both ports to study BW discharged near the Port, using MIKE21 HD and AD module. Winds and tides have been used to set up the model hydrodynamics. Model runs were undertaken to simulate the dispersion of salinity plume created by BW.
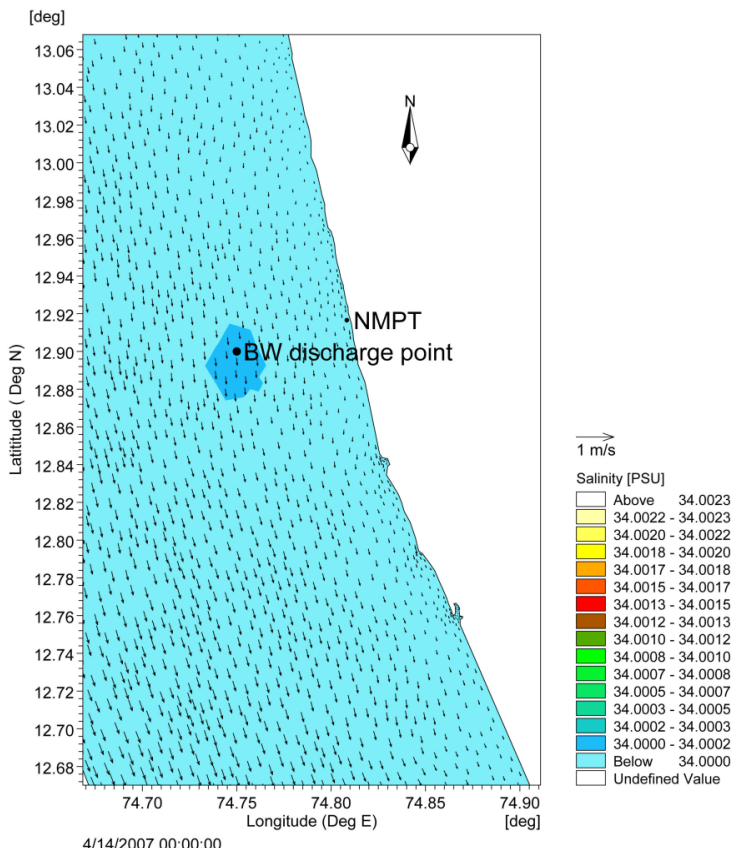

(A)

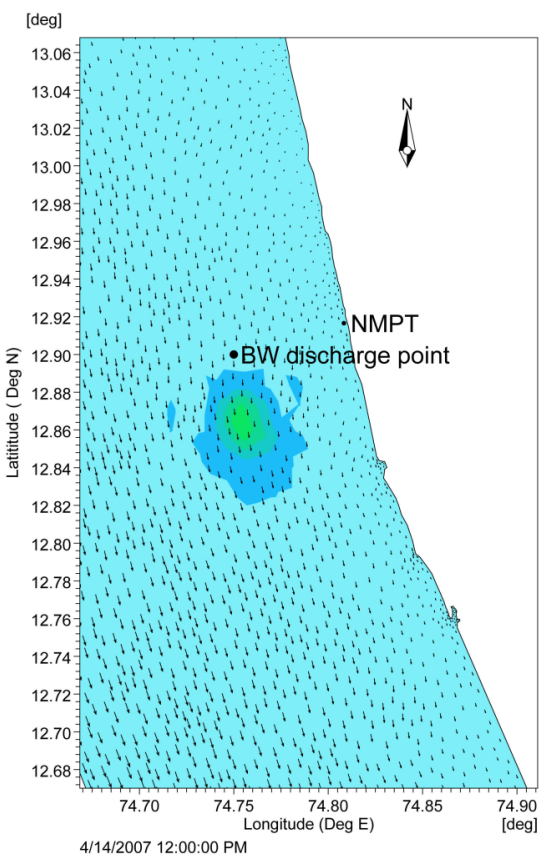

(C)

\subsection{New Mangalore Port}

The current data measured off Mangalore, Mulki and Suratkal, during April and May 2007, covering both spring and neap phases of the tide were used to setup the model for BW dispersion off Mangalore.

Off Mangalore the discharge point considered lies near the spoil ground located at $12^{\circ} 54^{\prime} \mathrm{N}$ and $74^{\circ} 45^{\prime} \mathrm{E}$ at a depth of $15 \mathrm{~m}$. The dispersion pattern of the particles were simulated, and the resultant salinity plumes during flood and ebb currents were analysed.

The currents were predominantly southerly and the maximum current speed observed off Suratkal and Mulki was $0.40 \mathrm{~m} / \mathrm{s}$. There were frequent spells of current reversals during which weak northerly currents were present. After setting up the numerical model for HD, the dispersal of salinity of the BW were studied as a tracer to

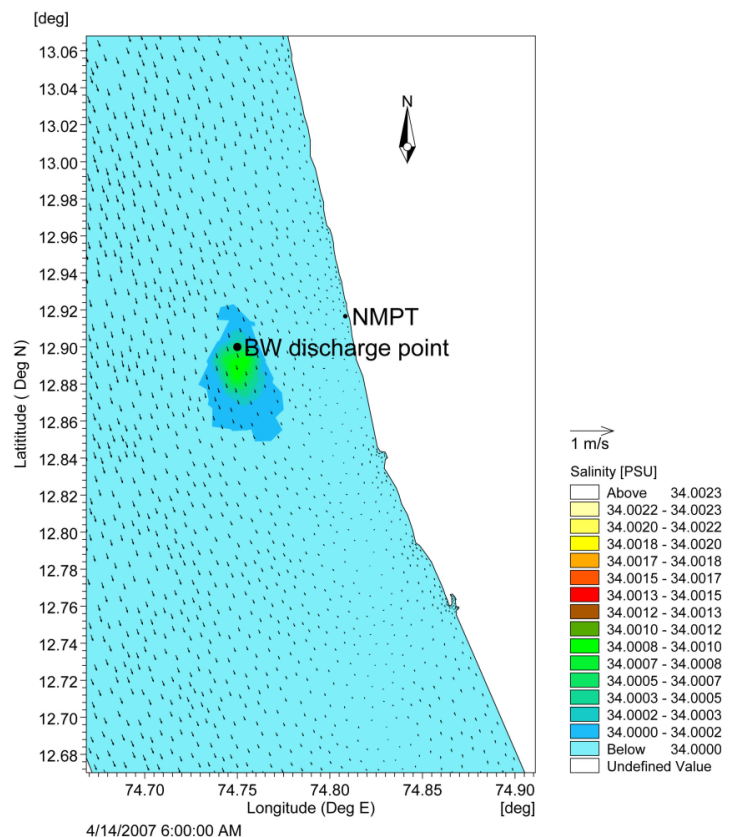

(B)

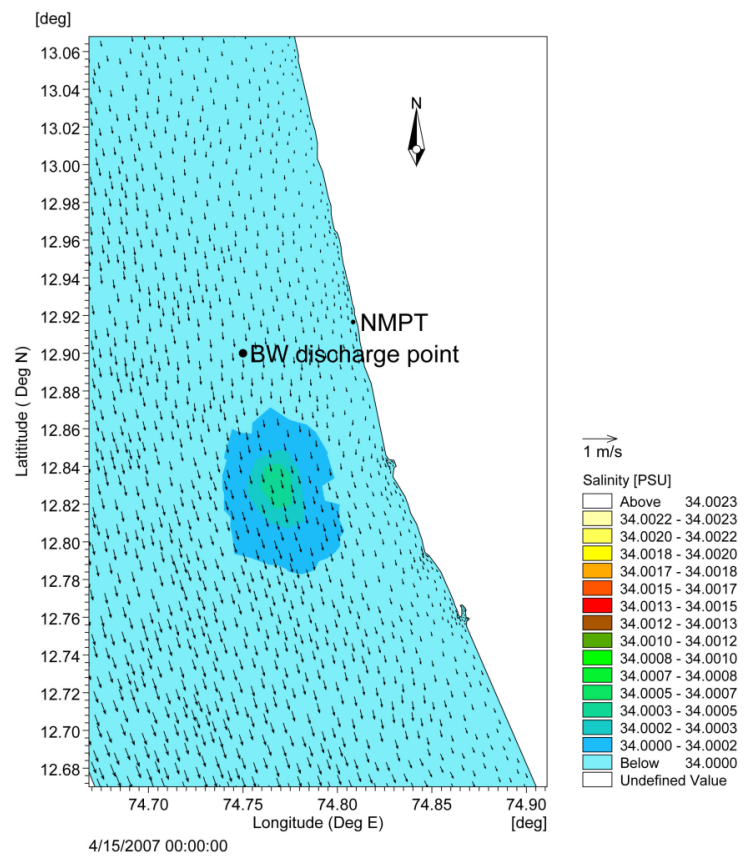

(D)

Figure 4. Modelled trajectory of ballast water salinity plume generated off Mangalore, west coast of India, over a period of two days; (A) immediately after completion of discharge; (B) after 6 hours; (C) after 12 hours; (D) after 24 hours. 


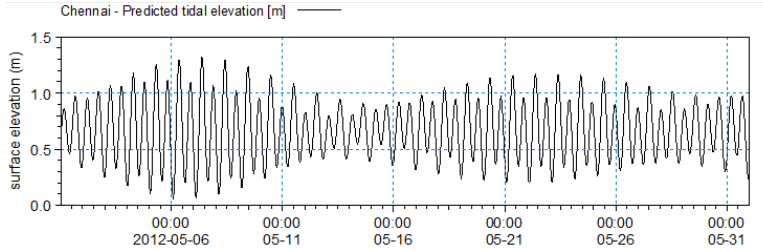

(A)

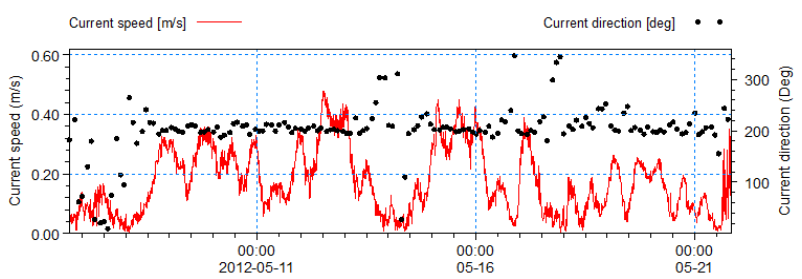

(B)

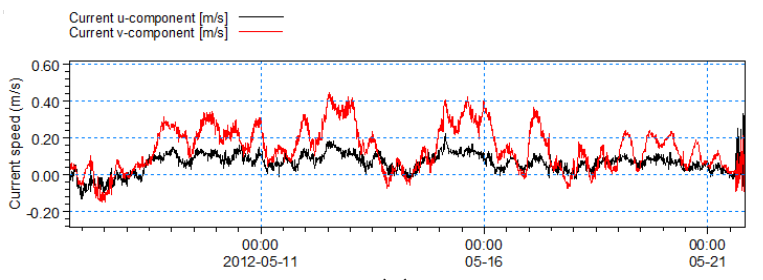

(C)

Figure 5. Modelled and predicted surface (tidal) elevations and currents off Chennai, east coast of India, in May 2012. (A) Predicted surface tidal elevation; (C) current speed and direction; (D) v- and u-component of currents.

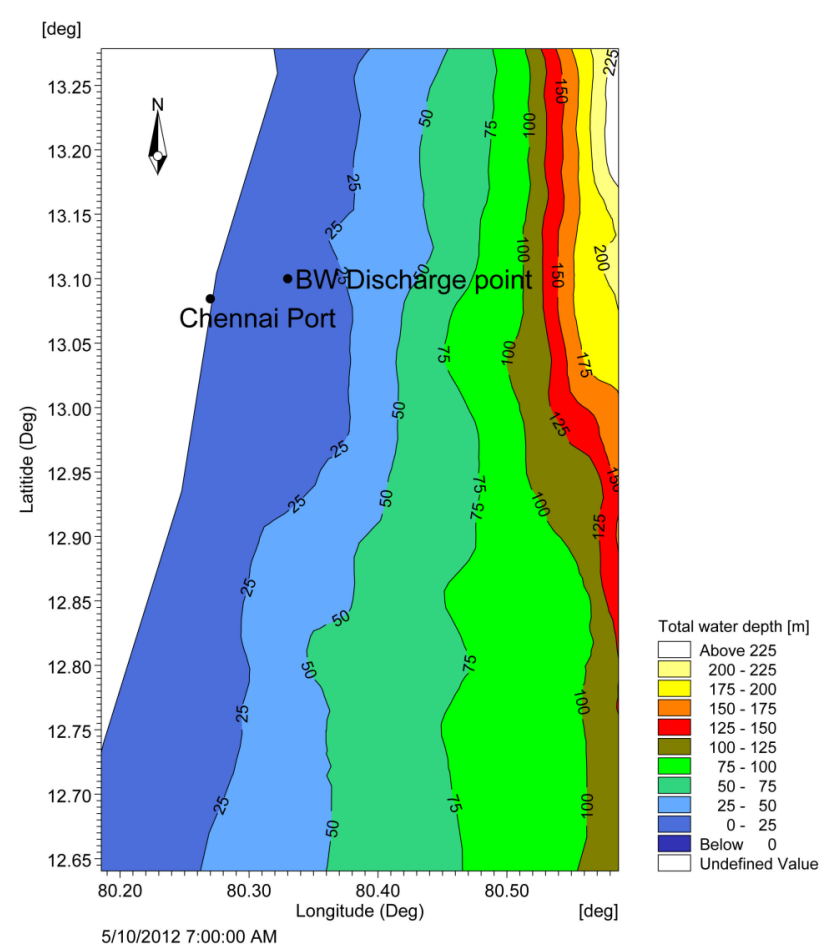

Figure 6. Depth profile in the vicinity of the ballast water discharge location ( $\left.13^{\circ} 06.250^{\prime} \mathrm{N}, 80^{\circ} 19.485^{\prime} \mathrm{E}\right)$ off Chennai Port, east coast of India.

track BW. The model was applied to simulate the trajectory of salinity discharged through BW at a location close to the spoil ground located at $12^{\circ} 54^{\prime} \mathrm{N}$ and $74^{\circ} 45^{\prime} \mathrm{E}$ at a depth of $15 \mathrm{~m}$ off New Mangalore Port (Figure 2). The simulated currents were validated with the measured $\mathrm{u}$ (zonal) and v (meridional) current components and surface elevation obtained off Mangalore (Figure 3).

The dispersion of the salinity plume is simulated using MIKE21 module and the resultant salinity plume pat- tern at the completion of discharge, and after $6 \mathrm{~h}, 12 \mathrm{~h}, 24$ $\mathrm{h}$ and $48 \mathrm{~h}$ are given in Figure 4 . The trajectory of the particles exhibited a southward or northward movement under the influence of the reversing coastal currents.

\subsection{Chennai Port}

A Recording Current Meter (RCM) was deployed off Chennai Port in the vicinity of the spoil ground located at $13^{\circ} 06.250^{\prime} \mathrm{N}$ and $80^{\circ} 19.485 \mathrm{E}$ at a depth of $16 \mathrm{~m}$. The deployment was continued for a period of 4 weeks (3-29 May 2012). The currents were mostly northward, flowing parallel to the coast with a maximum speed of $0.47 \mathrm{~m} / \mathrm{s}$. The details of the measured current data are shown in Figure 5. Currents were northerly with strong v-component of $0.47 \mathrm{~m} / \mathrm{s}$. The BW discharge location is shown in Figure 6 . The plume pattern obtained after a period of $6 \mathrm{~h}, 12 \mathrm{~h}, 24 \mathrm{~h}$ and $48 \mathrm{~h}$ are shown in Figure 7 . The salinity plume moves northward under the prevailing northerly currents and crossed the northern model boundary after $48 \mathrm{~h}$.

BW discharge point is located off Chennai Port at $13^{\circ} 06.250^{\prime} \mathrm{N}$ and $80^{\circ} 19.485^{\prime} \mathrm{E}$, at a depth of $15 \mathrm{~m}$. A source of 3000 tons $/ \mathrm{h}$ is defined at this location as BW discharge. The discharge of BW was continued for about $7 \mathrm{~h}$ to complete the hypothetical release of 21,000 tons of BW. Initially, the high salinity plume particles showed northsouth oscillation associated with tidal propagation but exhibited a net northward advection under the prevailing northerly coastal currents. The plume moved southward during ebb current and northward during flood current. At no point of time the plume showed any movement or spreading towards the Port or nearby coast. Plume showed spreading around the discharge location after 12 $\mathrm{h}$ of discharge, then moved northward, and finally moved out of the model domain after $24 \mathrm{~h}$ of discharge. Therefore, it is suggested that this location is suitable for the release of BW carried by the ships visiting Chennai Port.

\section{CONCLUSIONS}

In the case studies presented here, the model results as well as the measurements indicate that the predominant currents were southward off Mangalore and northward off Chennai during the study period (pre-monsoon period). Though the particles exhibited reversal associated with the tidal currents, the net transport of the particles were southward off Mangalore and northward off Chennai.

The model simulation studies carried out for Mangalore and Chennai ports showed that during the southwest monsoon period when the currents were northward, the discharged BW and the particles advected northward, parallel to the coast. The maximum currents measured was about $0.47 \mathrm{~m} / \mathrm{s}$ which helped in achieving higher dilution of the BW discharge. Though the high salinity plume was seen at the source during the discharge, it advected northward from the source after a period of $10 \mathrm{~h}$. After this period, ambient salinity present in the vicinity of the discharge location.

It may be noted that the currents are predominantly tide-driven in the ports situated along the west coast of India and the circulation exhibits reversals associated with the phase of the tide off Mangalore. However, off Chennai Port, which is situated along the east coast of India, the particles advected either southward or northward under the prevailing coastal currents present in the offshore region and experienced comparatively less impact of the tide reversals. This information is very vital and useful in selecting suitable locations for monitoring 


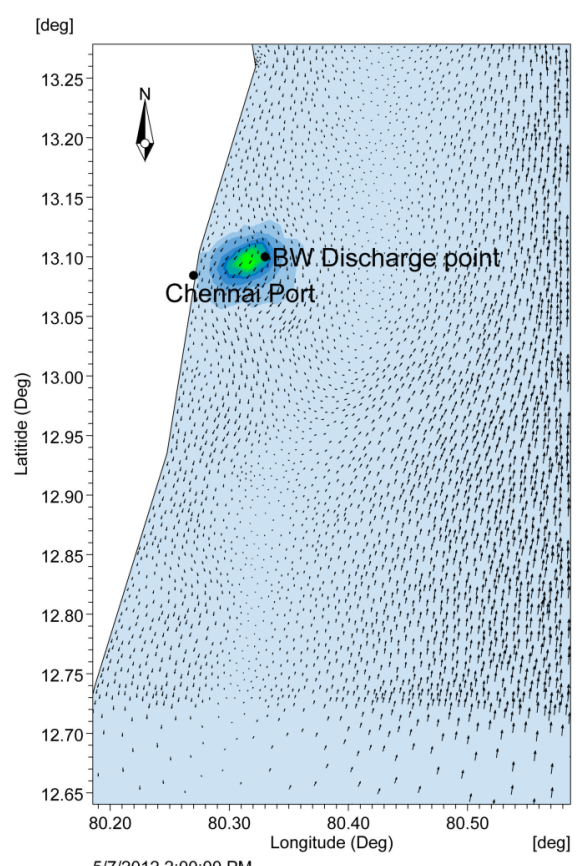

(A)

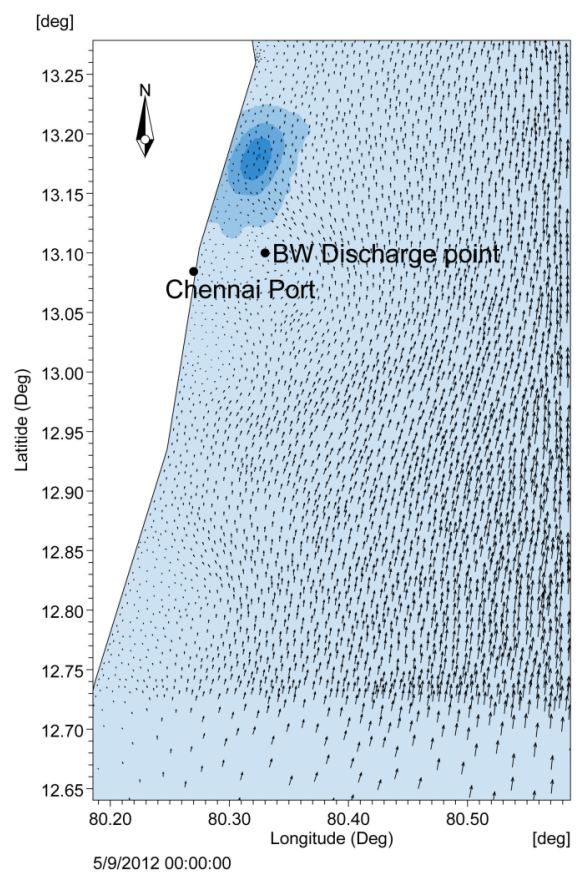

(C)
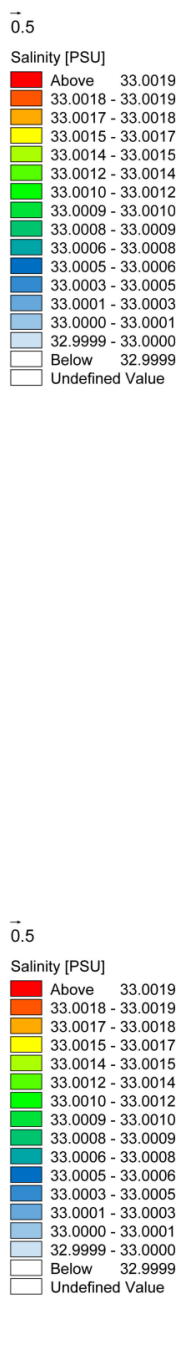

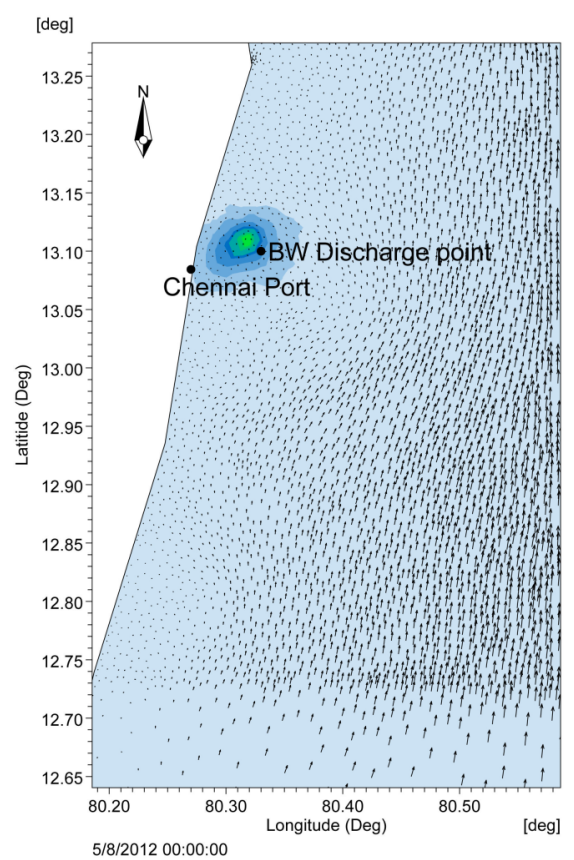

(B)

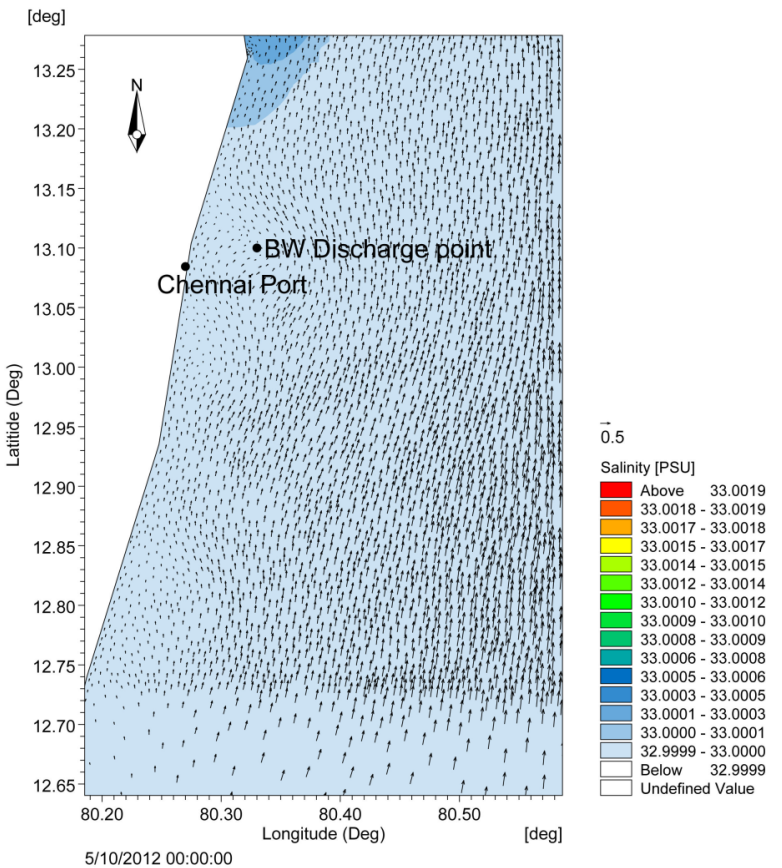

(D) $\overrightarrow{0.5}$

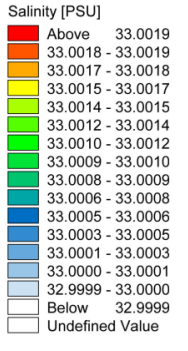

Figure 7. Modelled trajectory of ballast water salinity plume generated off Chennai, east coast of India, over a period of two days; (A) immediately after completion of discharge; (B) after 6 hours; (C) after 12 hours; (D) after 24 hours.

points needed for field sampling and measurements for BW release (Albert et al. 2013). In this context, the results obtained from ballast water dispersion modelling studies conducted off Mangalore and Chennai are quite essential for developing and assisting port-based ballast water management projects for CIO-I and CIO-II regions.

\section{ACKNOWLEDGMENTS}

We thank the ASEAN Committee for Science and Technology (COST) and Ministry of External Affairs, India for their generous support. We thank Director, CSIR-NIO for his support and encouragement. The contents of this manuscript were first presented at the ASEAN-India international conference on the extent of transfer of alien invasive organisms in South/Southeast Asia region by shipping, held in Chiang Mai, Thailand from 26 to 28 November 2013.

\section{REFERENCES}

Albert RJ, Lishman JM, Saxena JR. 2013. Ballast water regulations and the move toward concentrationbased numeric discharge limits. Ecological Applications 23:289-300.

Endresen O, Behrens HL, Brynestad S, Andersen AB, Skjong R. 2004. Challenges in global ballast water management. Marine Pollution Bulletin 48(7-8):615-623.

Gollasch S, Leppäkoski E. 2007. Risk assessment and management scenarios for ballast water mediated species introductions into the Baltic Sea. Aquatic Invasions 2(4):313-340. 
Medcof JC. 1975. Living marine animals in a ship's ballast water. Proceedings of the National Shellfish Association 65:11-12.

Reise K, Gollasch S, Wolff WJ. 1999. Introduced marine species of the North Sea coasts. Helgoländer Meeresuntersuchungen 52:219-234.

Smayda TJ. 1990. Novel and nuisance phytoplankton blooms in the sea: evidence for a global epidemic. In: Graneli E, Sundstrom B, Edler L, Anderson DM, editors. Toxic marine plankton. New York: Elsevier. p. 29-40.
Stankiewicz M, Ljungberg R, Helavuori M. 2010. Ballast water management in the Baltic Sea. WMU Journal of Maritime Affairs 9(2):201-211.

Werschkun B, Banerji S, Basurko OC, David M, Fuhr F, Gollasch S, Grummt T, Haarich M, Jha, AN, Kacan S, et al. 2014. Emerging risk from ballast water treatment: the run up to the International Ballast Water Management Convention. Chemosphere 112:256-266. 